\title{
The Effect of Betel Quid Extract on Wound Healing Process in Male Wistar Rats (Rattus norvegicus L.)
}

\author{
Siti Rusdiana Puspa Dewi ${ }^{*}$, Adelina Fatonah ${ }^{2}$ \\ ${ }^{1}$ Departement of Biomedical Science, Study Programme of Dentistry, Medical Faculty, Universitas Sriwijaya \\ Jl. Palembang-Prabumulih km.32 Inderalaya, Indonesia \\ ${ }^{2}$ Student of Study Programme of Dentistry, Medical Faculty, Universitas Sriwijaya \\ Jl. Palembang-Prabumulih km.32 Inderalaya, Indonesia \\ *Corresponding author's email: sitrus_pd [AT] yahoo.com
}

\begin{abstract}
Wound can be occured during dental treatment. In outline, there are several phases of wound healing; inflammatory phase, proliferative phase, and maturation phase. Various drugs in various forms are used to accelerate the healing process, but mostly they have side effects. Therefore, traditional medicine, such as betel quid consisted of betel leaf, areca nut, gambier, and calcium hydroxide, is developed. The aim of this study was to investigate the effect of wound healing process in male Wistar rats. A total of 30 male Wistar rats were taken and divided into 5 groups: Group 1, 2, and 3 (K1,K2, K3) were given 5\%, $10 \%$ and $15 \%$ concentrations of betel quid extract oinments; Group 4 (K4) was positive control (hyaluronic acid $0.2 \%$ oinment); Group 5 (K5) was negative control (placebo oinment). One mm-diameter of lower lip mucosal wounds on rats were created by using cylinder diamond bur. The oinments were applied twice daily for 10 days. The number of netrophils on first and third day were measured and the thickness of ephitelium on 10 days were determined. All groups of betel quid extracts exhibited the reduction of the number of neutrophils on inflammatory phase. Group 3 shown as the highest effect and had no significant different with positive control. Betel quid extracts in all groups also improved epithelial thickness on proliferative phase, in which group II and group III had no significant different with positive control. Betel quid extract had effect on wound healing process in male Wistar rats due to its ability in supressing inflamation and in increasing reepithelization.
\end{abstract}

Keywords — anti-inflammatory, betel quid, ephitelial thickness, wound healing

\section{INTRODUCTION}

Wounds or injuries to the oral cavity often occur due to some dental procedures such as scaling, root planning, and trauma. Wound is a disruption of the cellullar and anatomical tissue continuity resulting from physical, mechanical, chemical, thermal, or radioactive substance [1,2]. Those wounds or injuries stimulate biological process as a response through a complex and dynamic recovery process causing continuous recovery of anatomy and function called wound healing [3,4]. A completely healed wound is interpreted that the tissue has been backed to normal anatomical structure, functional, and its appearance [5].

Basically, the wound healing process is divided into several phases; inflammatory phase, proliferative or fibroplasial phase, and remodelling or maturational phase [6]. The inflammatory phase is characterized by hemostasis [4]. Hemostasis refers to platelet aggregation and platelet plug formation [7]. Platelet activity is linked to the initiation of clotting cascades. The aggregation of thrombocytes and platelets in fibrin network forms coagulation. This activity associated with minimizing blood loss [8]. Insoluble fibrin generated by proteolytic coagulation cascade stabilizes the blood clot. ${ }^{7}$ In another site, wound and activation of clotting factor induces the release of inflamatory mediators such as thromboxane A2, prostaglandin, histamine. Those mediators promote clinical signs of inflamation, such as rubor, kalor, dolor, tumor and functiolaesa [9,10]. After several hours of wounding, neutrophils appear into injury's area. These phagocytic cells have responsibility in debris scavenging, killing bacteria, and decontaminating the wound from foreign organism. Neutrophils eliminate microbes and dead cells through phagocytosis, or by releasing free radicals. Neutrophils perform the process of marginization, adhesion, and migration before starting their phagocytosis function [11,12]. Neutrophils together with another anti inflamatory cells induce angiogenesis in proliferative phase. 
Proliferative phase begins on the third day of injury and ends on the $14^{\text {th }}$ day thereafter. This phase is responsible for the closure of wound. It is characterized by the process of angiogenesis, fibroplasia, and reephitelization [5,13]. Keratinocytes were migrated in a few hours after injury. Keratinocyte promotes protein secretion to produce basement membrane, stimulate reepithelization and wound closure [14]. Nutrients and oxygen are needed in wound repair, so that formation of blood vessels or angiogenesis are induced [15]. Cytokines, produced by neutrophils, together with growth factors (PDGF, TGF-b, bFGF), present the migration of fibroblast. Fibroblasts proliferate and form granulation tissue [16]. The tissue will complete wound closure, provide cell adhesion, proliferation and differeniation during wound healing [14,16]. The last phase of wound healing is remodelling or maturation phase, which starts from two weeks after lesion up to one year depending on the severity of the wound. The phase is marked by the maturing of extracellular matrix through restructurization, degradations and reshynthesis of matrix [6]. Extracellular matrix has many functions, such as delivering cytokines and growth factor, tissue repair, controlling morphogenesis, regulating cell activities and bioavaibility [17,18].

Many drugs are used to heal the wound, such as topical hyaluronic acid. Dechet et al. stated that $0.2 \%$ hyaluronic acid gel has important role in regulating the cell proliferation. However, some adverse effects may occur, such as allergic reaction, tissue necrosis, infection, and etc [20]. Therefore, natural substances as alternative medicine are develop as substitute, i.e betel quid.

Chewing betel quid has been commonly practiced by many people all over the world, like Indonesia, Malaysia, India, Bangladesh, and Taiwan. Chewing betel quid habit has many impacts on social, cultural, religious and economic life, and received special attention in the past. In addition, people used to believe that it can strengthen their teeth and relieve toothache. Betel quid is a mixture of areca nut (Areca catechu L.), gambier (Uncaria gambir Roxb.), mineral slaked lime (calcium hydroxide) wrapped in betel leaves (Piper betle L.) [21]. All ingredients of betel quid are capable of accelerating wound healing process.

Betel leaf has long been used as a household remedy for oral mucosal inflammation [22]. Previous study has been reported that betel leaf has active compound including essensial oil (hydroxyl chavicol, eugenol, chavicol, chavibethol, estragol, terpene, sequiterpene, triterpenoid, $\beta$-cytosterol) and tannin [23]. Lin et al mentioned that phytochemical compounds contained in betel leaf was effective to inhibit inflammatory reaction and stimulate reepithelization process on wound healing [24].

The areca nut is the dark red seed of Areca catechu that has reported to have several therapeutic properties, including analgesic, anti-inflammation and antioxidant, and has a role in wound healing. The areca nut extract contains procyanidin, the main condensed tannin which widely disperses to the polyphenolic compounds and has pharmacological effects [25]. Vonna et al mentioned that the ethanol extract of areca nut had wound healing activities in Mus musculus albinus mice [26].

Gambier plants (Uncaria gambir Roxb.) also have a role in wound healing, i.e antioxidant, antiseptic, anti-inflammation, and cell proliferation, as they have the main content of catechin [27-31]. In addition, gambier contains polyphenol groups such as alkaloids, terpenoids, flavonoids, and other polyphenolic compounds. Another components contained in the gambier are catechu tannat, pyricatechol, red catechu, quercetin and fixed oil. The content of flavonoid takes part on wound healing process by increasing collagen formation, decreasing macrophages and tissue edema and increasing the amount of fibroblasts [32].

Mineral slaked lime has chemical formula of $\mathrm{CaOH}_{2}$ (calcium hydroxide). Calcium hydroxide has been shown to have antimicrobial properties and reduce periapical inflammation, so it is increasingly being used. Calcium hydroxide paste has a high $\mathrm{pH}$ of 12.5 to 12.8 . The high alkaline nature of the calcium hydroxide is able to neutralize the acid (buffer), reduce the inflammatory reaction and stimulate healing $[31,33,34]$.

The purpose of this study was to determine the effect of wound healing extract of betel quid on male rats Wistar strain. Wound healing process was investigated by evaluating the anti-inflammatory effect and reepithelization thickness of wound in vivo.

\section{METHODOLOGY}

The study was true experimental in vivo with pretest-posttest control group design design to know anti-inflammatory effect and posttest only control group design to know the effect of reepitelization on wound healing of betel quid extract. The study protocol had been approved by Research Ethical Commission of Mohammad Hoesin General Hospital (RSMH) Palembang and Medical Faculty of Sriwijaya University with ethical certificate No. 391/kepkrsmhfkunsri/2017.

\section{Animals}

The study was carried out using Wistar ((Rattus norvegicus L.) rats weighing 150-200 grams, 8-12 weeks old, obtained from Pharmacy School of Bandung Institute of Technology (SF-ITB), with certificate no. 519.2/3691-Dispangtan/2017. Rats were raised in the Animal House of the Medical Faculty of Sriwijaya University. They were maintained under standar housing 
conditions at room temperature of $20^{0}-25^{0} \mathrm{C}$ with dark-light cycle $12 \mathrm{~h} / 12 \mathrm{~h}$. The animals were acclimatized to laboratory condition for eight days before study [35]. During acclimatization process, rats were fed with standard pellet diet and water $a d$ libitum.

Thirty male Wistar rats were divided into 5 groups, Group I (K1) was treated with $5 \%$ betel quid extract ointment, Group II (K2) was treated with $10 \%$ betel quid extract ointment, Group III (K3) was treated with $5 \%$ betel quid extract ointment, Group IV (K4) was positive control, treated with $0.2 \%$ hyaluronic acid ointment (purchased from Ricefarma Pharm.Co, Surabaya, Indonesia), and Group V (K5) was negative control, treated with placebo oinment.

\section{Plant materials}

Betel quid components, including betel leaf (Piper betle L.), areca nut (Areca catechu L.), gambier (Uncaria gambir Roxb.) and mineral slaked lime (calcium hydroxide) were collected from Babatoman Village, Sekayu Subdistrict, Musi Banyuasin District, South Sumatra Province, Indonesia. All the components and material were identified and authenticated by Faculty of Agriculture, Sriwijaya University, Indonesia.

\section{Extraction of betel quid}

Betel quid was extracted by using soxhletation method. Betel quid components consisting of $8 \mathrm{~g}$ of betel leaf, $3.5 \mathrm{~g}$ of areca nut, $2.5 \mathrm{~g}$ of gambier and $2 \mathrm{~g}$ of betel lime were mixed and were placed in thimble made from cellulose. Soxhlet apparatus was filled with $96 \%$ ethanol solvent at ratio of $1: 4$ and heated at temperature of $50^{\circ} \mathrm{C}$ for five hours. The extract was filtered and concentrated in vacuum reduced pressure using rotary flash evaporator (IKA RV10, Staufen, Germany) for 48 hours, until solvent had been removed.

\section{Preparation of ointment}

Betel quid extract was formulated as oinments by different concentration of 5\%,10\% and $20 \%$. The dose given to experimental rats was $50 \mathrm{mg}$. The basic materials for ointment were lipid based material consisted of $15 \%$ adeps lanae and $85 \%$ vaselin album. The base was prepared by weighing accurately. The hot mortar and pestle was taken out from oven (ColePalmer Ltd, UK) and adeps lane was poured into mortar and stirred by using pestle until melt. Subsequently, vaseline album was poured into mortar and was stirred by using pestle gently until homogenous and form ointment base. Betel quid extract was added according to formulation of respective groups and was stirred until homogenous. In preparing placebo oinment, the base was taken and treated in the same manner to formulate oinment without any active ingredients. Ointment extract was flattened on surface of glass base for subsequent homogenity test. An ointment was considered homogenous if particles mixture was evenly distributed. Homogenous ointment preparations extract was put into ointment pot and was labeled according to treatments.

\section{Preparation of $1 \%$ carrageenan}

0.05 grams of carrageenan was weighed and suspended in $5 \mathrm{ml}$ of $0.9 \% \mathrm{NaCl}$ solution in the measuring flask.

\section{Induction of mucosal wound}

Lower lip mucosal wound was induced by using 1-mm diameter of cylinder diamond bur (Microdont, USA). Prior to wound induction, animals were anesthetized with $0.2 \mathrm{~mL}$ ketamine by i.m. injection. The lower lip of rats was withdrawn by using tweezer (Fisher brand ${ }^{\mathrm{TM}}$, Thermofisher Co, UK) and was swabbed with aquadest-wetted sterile cotton. Mucosal wound was made by using cylinder diamond bur at depth of about $1 \mathrm{~mm}$ in accordance to bur diameter used in this process. Blood was cleaned with aquadest-wetted sterile cotton and dried. Carrageenan was injected intraorally in another side of lower lip of rat. Five hours after injection, blood samples were taken and sent to Province's Health Laboratory of South Sumatera, Indonesia, to count the number of neutrophil.

\section{Topical wound application}

Ointments were applied respectively by using sterile cotton bud on lower lip mucosal wound of rats twice daily, every 12 hours, and lasts for 10 days. On the first day, oinments were given immediately after induction of wound. To avoid contact with the wound, rats were isolated from eating and drinking for 1 hour after treatment.

\section{Counting the number of Segmented neutrophil cells}

The number of neutrophil cell was performed using a hematology analyzer (Yumizen H500®, Horiba Medical Equiptment Co., Japan). Blood samples were taken on the first day post induction of carrageenan and the third day, after 6 times application of oinments for 3 days. Blood samples were taken from sinus orbita of rat eyes, then placed on a tube containing anti-coagulant 
ethylene diamine tetra acetic acid (EDTA) purchased from Province's Health Laboratory of South Sumatera, Palembang, Indonesia. Furthermore, the number of segmented neutrophil cells in rat blood were calculated.

\section{Histological Assessment}

Wistar rats were euthanized by using chloroform in the 11th days. The mucosal wound were taken by using surgical scissor (Surgipro Inc, Germany). The speciments was fixed in $10 \%$ formalin solution and stained with haematoxylin and eosin (H and E) prepared by Anatomical Pathology Laboratory of Dyat Natalis, Palembang, Indonesia. To reduce subjective bias, all assessment were made with histological slides coded. Epithelial thickness of all samples was evaluated by a histo-pathologist.

\section{Microscopic assessment}

The speciments were observed through optical microscope with 400x magnification in 5 fields of view. The observed structure was the epithelial layer from stratum corneum to stratum basal. The pictures of speciments was taken by using Microocular MD130 electron eyepiece (Ome-Top System Co., Ltd, Taiwan). The newly formed epithelial thickness from the picture was measured and analiyzed.

\section{Statistical analysis}

The data of the neutrophil cell numbers and reephithelization thickness were collected and analyzed statistically using SPSS vers 22 (IBM ${ }^{\circledR}$ inc.pvt ltd, US). Both data were performed with Levene's test to know the homogenity of samples and normality test of Shapiro Wilk to know the distribution of samples. P value of $>0.05$ was considered that data were homogen and normal. To compare the changes of the neutrophil cells between before and after study, we used paired t-test. One-way Anova was used for analyzing the significant differences in all groups, followed by Tukey's post hoc test for multiple comparisons. The $\mathrm{p}$-value less than 0.05 was regarded as statistically significant.

\section{RESULTS AND DISCUSSION}

\section{Evaluation of the number of neutrophil cells in the inflammatory phase of wound healing}

Normality and homogeinity test had been carried out and the result showed $\mathrm{p}$ value $>0.05$, so it meant that the data were normally distributed and homogen. The mean of neutrophil cells in betel quid groups after treatment reduced significantly compare to before treatment (table 1). The higher concentration of betel quid extract, the lower number of netrophil cells in blood. The lowest number of netrophils cells was exhibited in hyaluronic acid group. The decreasing on the number of neutrophil was also shown in placebo. It was happened because on the 3rd day, neutrophil cells began to decrease and were replaced by macrophages on the 4rd day.

Table 1. Comparison of the number of neutrophils before and after treatment

\begin{tabular}{cccc}
\hline Group & Means of neotrophil cells (\%) & \multirow{2}{*}{ P Value* } \\
\cline { 2 - 3 } & Pre-test & Post-test & $0.003^{*}$ \\
\hline K1 (5\% betel quid extract) & $28.83 \pm 3.66$ & $16.83 \pm 3.06$ & $0.000^{*}$ \\
\hline K2(10\% betel quid extract) & $29.17 \pm 5.38$ & $14.33 \pm 3.14$ & $0.000^{*}$ \\
\hline K3 (20\% betel quid extract) & $29.50 \pm 2.58$ & $9.17 \pm 3.60$ & $0.000^{*}$ \\
\hline K4 (positive control) & $29.67 \pm 5.46$ & $6.33 \pm 3.14$ & $0.002^{*}$ \\
\hline K5 (negative control) & $28.17 \pm 7.73$ & $19.00 \pm 6.93$ & \\
\hline
\end{tabular}

*Paired t test, $p=0.050$

Result of one-way ANOVA of $\mathrm{p}$ value $<0.000$ implied that betel quid extract had significant effect in reducing the number of neutrophils, so it was able to accelerate the wound healing process.

Post Hoc Tukey's were done to compare betel quid extract with positive and negative control groups. Table 3 showed that $20 \%$ betel quid extract had ability in decreasing neutrophil cells compare to negative control and had no significant difference with positive control group ( $0.2 \%$ hyaluronic acid). 


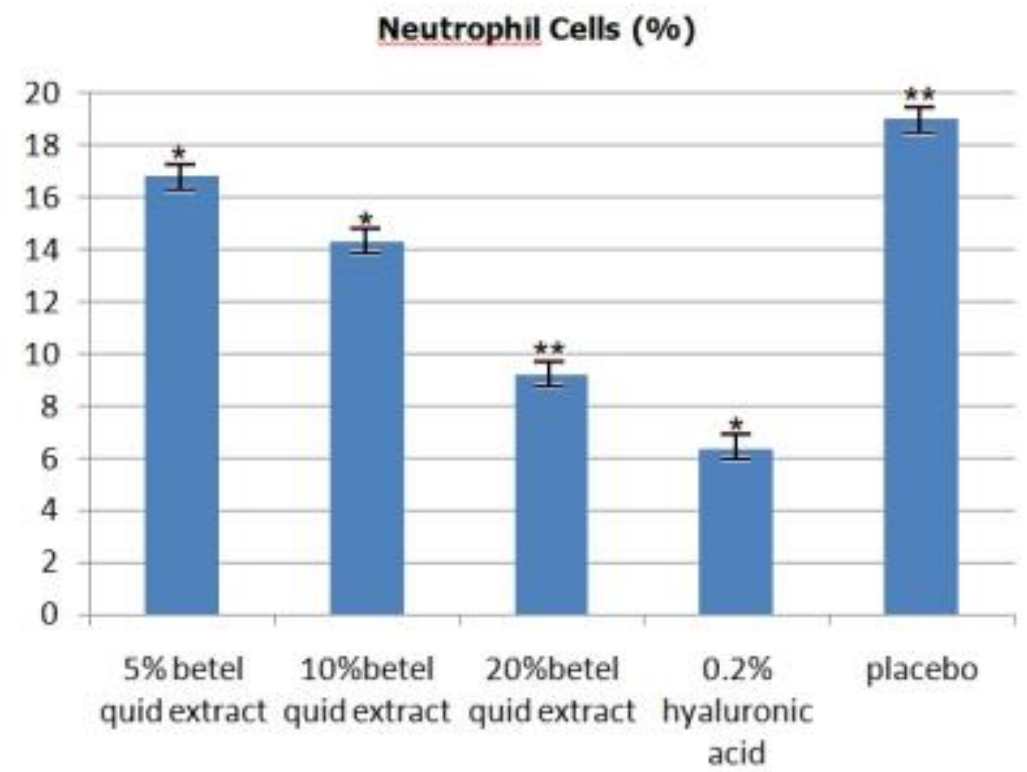

Figure 1. The number of neutrophils. Betel quid extract of $20 \%$ concentration displayed anti-inflammatory effect significantly and data were expresses as mean $\pm \mathrm{SD}, * \mathrm{p}<0.05$ versus positive control group; ${ }^{*} \mathrm{p}<0.05$ versus negative control group.

\section{Evaluation of epithelial thickness on proliferation phase of wound healing}

Normality and homogeneity test were done, and the results showed $p>0.05$. That meant data were normal and homogen. One-way ANOVA was performed and the result was $p$ value of $<0.05$.

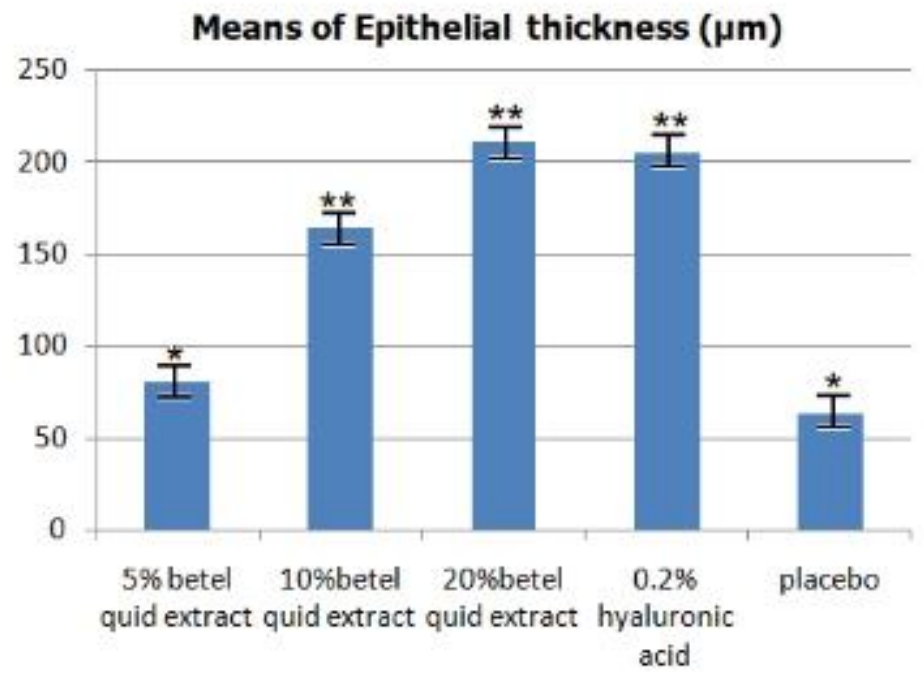

Figure 2. Epithelial thickness of wound. Betel quid extract of $10 \%$ concentration stimulated re-ephithelization significantly and data were expresses as mean $\pm \mathrm{SD},{ }^{*} \mathrm{p}<0.05$ versus positive control group; ${ }^{* *} \mathrm{p}<0.05$ versus negative control group. 
The epithelial thickness of wound assay was used to evaluate the epithelial cell production in the proliferation phase on wound treated with 5\%,10\% and 20\% betel quid extracts. Re-epithelization of wound increased at concentration of $10 \%$ and $20 \%$ when compared to negative control $(\mathrm{p}$ value $<0.05)$ and had no significant difference with positive control. It revealed that $10 \%$ betel quid extract had similar proliferative effect to $0.2 \%$ hyaluronic acid.

From the results, it had been proved experimentally that betel quid extract had potential effect in accelerating wound healing process. The effectiveness of betel quid extract was according to our findings that the extract had ability in reducing the number of neutrophils on the 3rd day of wound and boosting the re-epithelization on the 11th day of wound. The role of extract in inflammation and proliferation phase hastened the wound healing.

$20 \%$ betel quid extract had the same effectivity as $0.2 \%$ hyaluronic acid in decreasing inflammatory cells. The reduction of the cells expedites the healing to the next phase, namely proliferation phase. This study also revealed that after 11 days, reepithelization of $15 \%$ betel quid extract was similar to $0.2 \%$ hyaluronic acid on mucosal wound. The presence of new epithel on $20 \%$ betel quid extract was thicker than $0.2 \%$ hyaluronic acid. The findings underlined the ability of betel quid extract to accelerate the proliferation contributing to fast the healing process.

The effect of wound healing is due to its phytoconstituents of betel quid extract. Betel quid are consisted of betel leaves (Piper betle L), areca nut (Areca catechu), gambier leaves (Uncaria gambier) and calcium hydroxide. Previous study has explained that each compositions had their own active compound that help in stimulating wound healing process. These findings exhibit that all ingredients of betel quid has worked sinergistically for the healing process.

Piper betle contained in betel quid possess anti inflamatory properties, such as eugenol and hydroxychavicol [36]. Eugenol is potential as an anti inflammation, because it supresses the expression of cyclooxygenase-2 enzyme (Cox-2), TNF signaling, cytokines expression and production, and NF-kappaB. Eugenol inhibits prostaglandin synthesis and neutrophil chemotaxis [37,38]. Pin et al evaluated anti inflammatory activities of extract Betel leaves by using hyaluronidase (HYA), xanthine oxide (XOD) and lipoxygenase (LOX) inhibition assays, which plays important role in the leukotriene biosynthesis pathway and biological regulator systems of inflammatory dissorders. The results showed that Betel leaves extract represented high inhibition in XOD and LOX assays. Those activities were related to eugenol and hydroxychavicol contained in Betel leaves [39]. Eugenol in Piper betle has ability in inhibiting leukotrien C4 (LTC4) formation in the pathophysiology of inflammation [40]. Hydoxychavicol (HC) found in Piper betle is also potential as an anti inflammatory agents. HC induces the inhibition of COX-1/COX-2, the phrase of the pro inflammmatory cytokines TNF-a, platelet calcium signaling, and ROS scavenging $[33,41]$.

In proliferation phase, Piper betle contained in betel quid increases hydroxyproline content, a major part of collagen and essensial in collagen stability. Ghazali et al reported that Piper betle leaves extract improved re-ephitelization, fibroblast, collagen synthesis and deposition, and exhibited the decreasing of the oxidative stress markers [42]. Keat et al investigated that Betel extract increased wound contraction rate and protein content and created wound closure [43]. Lien et al stated that Piper betle Linn extract promoted wound healing by stimulating NIH3T3 fibroblast proliferation [44]. Nilugal et al reported that Piper betle leaves and stem extracts enhanced the rate of wound contraction and reducted healing time, highlighted by the full thickness coverage of organized tissue and collagen fibers on the wound [45].

Another composition of betel quid is Areca nut. Areca nut grows in several country such as Indonesia, Malaysia, India, Bangladesh, China, etc. Traditionally, areca nut are used for some medical use [46,47]. The major chemical properties of Areca nut are polyphenols (flavonoids and tannin), polysaccarides, proteins, fats, fibers, alkaloids, minerals, vitamin B and C [48]. The anti inflammatory effect of areca is related to the inhibition of cyclooxigenase-2, the reduction of the number of neutrophils, the release of prostaglandins (PGEs), IL-1, IL-6, leukotrienes, histamins, the suppression of T cell activities, and the induction of the release of IL-4 [46,49,50]. Areca nut also consists of procyanidin, a condensed tannin from flavonoid group, that plays important role in hampering NFkB, phospolipase, lipooxygenase, and cyclooxygenase [48,51]. Anthikat and Michael reported that Areca catechu was significantly inhibited oedema, induced by chronic inflammatory agents [52]. Areca nut posses antimicrobial constituents that keep the wound sterile, so that the wound healing process will be hastened. Alkaloids and polyphenols in areca nut accelerates wound healing by increasing wound contraction and breaking strength, and also enhancing hydroxyproline level in tissue granulation [53]. Verma et al revealed that Areca catechu promoted burn wound healing, by increasing wound contraction, reepithelization, as well as dexamethason [54]. Bharat et al also stated that Areca catechu was effective in expediting of wound healing process [55].

Gambier (Uncaria gambier Roxb.) as one of betel quid composition, has also been used in Indonesia for some medical reason, such as anti bacteria, antioxidant, anti-inflammation, analgesic, and antihypercholesteroemia. The main ingredient consisted in gambier that has inportant role in traditional medicine is catechins. Catechins are type of polyphenol and part of the flavonoid groups, that strongly has antioxidant effect [56]. The anti-inflammatory effect of catechins is due to its ability in 
reducing cyclooxygenase, lipooxygenase, and phospholipase enzyme activities. Once those enzymes are inhibited, the mediators of inflammations including prostaglandin and leukrotriene synthesis are disrupted [57]. Catechins decrease XO enzyme activities, NO production, NF-kB activation, pro inflammatory cytokines, TNF-a, IL-1, IL-2, IL-6, IL-6, IL-8, IL-12 and phospholipase $\mathrm{A}_{2}[58,59]$. Riswana et al revealed that gambier leaf acted as anti inflammatory because it created XO inhibitory activities [60].

The antibacterial and anti-inflammatory effect of gambier accelerate proliferation and remodelling process of wound healing. By keeping the wound sterile, the irritant is removed, the number of netrophils are reduced, the inflammatory phase is quicken, and the next phase of wound healing including proliferation and maturation phase are stimulated [61]. Sumosa et al reported that gambier in various concentrations influenced the time and percentage of wound healing process [62]. Septiani $e t$ al stated that ethanol gambier leaves lowered the width and length of wound, so the time of healing process was shortened [63].

Calcium hydroxide $\left(\mathrm{Ca}(\mathrm{OH})_{2}\right)$ is commonly use in dental procedure as analgesic, anti-inflammation, and regeneration of dental and periapical tissue. $\mathrm{Ca}(\mathrm{OH})_{2}$ is an inorganic compound that widely uses in many formulation of pulp capping, root canal medication and filling [64]. $\mathrm{Ca}(\mathrm{OH})_{2}$ reduces TNF-a protein and mRNA level, initiates vascular and inflammatory cell migration and proliferation to handle and remove irritating agents. It will stimulate fibronectin gene expression, mineralization, inhibit bacterial LPS, so that it can induce tissue regeneration, including migration and proliferation of mesemchymal and endothelial pulp cells, followed by collagen formation [65,66]. Kasaj et al evaluated periodontal wound healing of non-surgical periodontal patients, and proved that the application of oily calcium hydroxide suspension (Osteoinductal) mediated the wound healing process, by leading superficial necrosis. Thus necrosis caused inflammatory reaction, then the inflammatory layer is replaced by fibroblast [67]. Its biological and antiseptic effects are due to alkalinity and calcium ion release. The alkaline $\mathrm{pH}$ activates alkaline phosphatase and reinforces biomeneralization process. Slight necrosis on the surface layer induced by alkaline $\mathrm{pH}$ will precipitate wound healing [68].

\section{CONCLUSION}

Betel quid extract presents anti-inflammatory effect and wound re-epithelization on mucosal wound healing process and characterized as dose-dependant effect. This finding also contribute to find another mechanism of action of active ingredients from those plants for further study.

\section{REFERENCES}

[1] S. Dhivya, V. V. Padma, E. Santhini, "Wound dressings- a review," Biomedicine (Taipei), vol. 5, no. 4, pp 22-29, 2015.

[2] M. Sharma, B. S. Khajja, S. Jha, G.K Mathur, and V. N. Mathur, "Forensic interpretation of injuries/wounds found in the human body," Journal of Punjab Academic Forensic Medicine and Toxicology, vol. 11, no. 2, pp 105-109, 2011

[3] N. Ghanapathy, S. S. Venkataraman, R. Daniel, R. J. Aravind, and V. B. Kumarakhrisnan, "Molecular biology of wound healing," Journal of Pharmacy and BioAllied Sciences, vol. 2, no. 2, pp 334-337, 2012.

[4] H. Sinno and S. Prakash, "Complements and the wound healing cascade: an update review," Plastic Surgery International, vol. 2013, pp 1-7, 2013.

[5] K. Parthiban, S. Manikandan, and S. Ganesapandian, "Production of cellulose I microfibrils from Rhizobium sp. and its wound healing activity on mice," Asian Journal of Applied Sciences, vol 4, pp. 247-254, 2011.

[6] A. C. D. O. Gonzales, T. F. Costa, Z. A. Andrade, and A. R. A. P. Medrado, "Wound healing- a literature review," Anais Brasileiros de Dermatologia, vol. 91, no. 5, pp. 614-620, 2016.

[7] A. J. Gale, Current understanding of hemostasis,” Toxicologic Pathology, vol. 39, no. 1, pp 273-280, 2011.

[8] K. Ghoshal, and M. Bhattacharyya, "Overview of platelet physiology: its hemostatik role in disease pathogenesis," The Scientific World Journal, vol. 2014, pp. 1-16, 2014.

[9] S. Guo, and L. A. DiPietro, "Factors affecting wound healing," Journal of Dental Research, vol. 89, no. 3, pp. 219229,2010

[10] Flanagan M, "The physiology of wound healing," Journal of Wound Care, vol. 9, no. 6, pp. 299-300, 2000

[11] E. Kolaczkowska, "The older the faster: aged neutrophils in inflammation," Blood, vol. 128, pp. 2280-2282, 2016.

[12] D. J. Lee, H. Li, M. T. Ochoa, M. Tanaka, et al, "Integrated pathways for neutrophil recruitment and inflammation in Leprosy," The Journal of Infectious Disease, vol.201, no. 4, pp. 558-569, 2010 
[13] J. Li, J. Chen, and R. Kirsner, "Patophysiology of acute wound healing," Clinical Dermatology, vol. 25, no. 1, pp. 9-18, 2007

[14] A. Bhatia, K. O'Brien, M. Chen, D. T. Woodley, and W. Li, "Keratinocyte-secreted heat shock protein-90 alpha: leading wound reepithelization and closure," Advance on Wound Care, vol. 5, no. 4, pp. 176-184, 2016

[15] K. E. Johnson and T. A. Wilgus, "Vascular endothelial growth factor and angiogenesis in the regulation of cutaneous wound repair," Advance on Wound Care, vol. 3, no. 10, pp. 647-661, 2014

[16] P. Brainbridge, "Wound healing and the role of fibroblasts," Journal of Wound Care, vol. 22, no. 8, pp. 407-412, 2013

[17] M. Xue and C. J. Jackson, "Extracellular matrix reorganization during wound healing and its impact on abnormal scarring," Advance on Wound Care, vol. 4, no. 3, pp. 119-136, 2015

[18] P. Olczyk, L. Mancner, and K. Komosinska-Vasser, "The role of extracellular matrix components in cutaneous wound healing," BioMed Research International, vol. 2014, pp. 1-8, 2014

[19] T. A. Dechert, A. E. Ducale, S. I. Ward, and D. R. Yager, "Hyaluronan in human acute and chronic dermal wounds," Wound Repair and Regeneration, vol. 14, pp. 252-258, 2006.

[20] T. Tashiro, S. Seino, T. Sato, R. Matsuoka, Y. Masuda, and N. Fukui, "Oral administration of polymer hyaluronic acid alleviates symptoms of knee osteoarthritis : a double-blind, placebo-controlled study over a 12-month period," The Scientific World Journal, vol. 2012, pp. 1-8, 2012.

[21] R. Sahitha, "Effects of smokeless tobacco, betel quid and areca nut on oral mucosa," IOSR Journal of Dental and Medical Sciences, vol. 13, no. 2, pp. 8-11, 2014

[22] D. Rintu, M. Shinjini, M. Kaustab, P. Pramathadhip, P. S. Umesh, and E. R. Banerjee, "Anti-oxidant and antiinflammatory activities of different varieties of piper leaf extracts (Piper betle L.)," Journal of Nutrition and Food Sciences, vol. 5, no. 5, pp. 1-15, 2015.

[23] O. S. Kumari and N. B. Rao, "Phyto chemical analysis of Piper betle leaf extract," World Journal of Pharmacy and Pharmacheutical Sciences, vol. 4, no. 1, pp. 699-703, 2014

[24] L. T. Lien, N. T. Tho, D. M. Ha, P. L. Hang, P. T. Nghia, and N. D. Thang, "Influence of phytochemical in piper betle linn leaf extract on wound healing," Burns Trauma, vol. 3, pp. 23-30, 2015

[25] P. Pithayanukul, S. Nithitanakool, and R. Bavovada, "Hepatoprotective potential of extracts from seeds of Areca catechu and Nutgalls of Quercus infectoria," Molecules, vol. 14, pp. 4987-5000, 2015

[26] A. Vonna, R. Nurismi, and Misrahanum, "Wound healing activity of unguentum dosage form ethanolic extracts of Areca catechu l. nut in Mus musculus albinus," Banda Aceh : Universitas Syiah Kuala, vol. 15, no. 2, pp. 28-36, 2015

[27] T. Anggraini, A. Tai, T. Yoshino, and T. Itani, "Antioxidative activity and catechin content of four kinds of Uncaria gambir extracts from West Sumatra Indonesia," African Journal of Biochemistry Research, vol. 5, no. 1, pp. 33-38, 2015

[28] H. Katu, Sumintarti, I. K. Mattulada, R. Samad, M. Hatta, and S. As'ad, "Inhibitory concentration and minimum contact time gambir extract (Uncaria gambir Roxb.)againts bacterial growth Enterococcus faecalis," International Journal of Science: Basic and Applied Research, vol. 27, no. 3, pp. 239-246, 2016

[29] M. Yimam, Y. C. Lee, T. W. Kim, et al, "Analgesic and antiinflamatory effect of UP3005, a botanical composition containingtwo standardized extracts of Uncaria gambir and Morus alba," Pharmacognosy Research, vol. 7, no. 5, pp. 39-46, 2015

[30] S. R. P. Dewi, M. T. Kamaluddin, Theodorus, and R. Pambayun, "Anticariogenic effect of gambir (Uncaria gambir Roxb.) extract on enamel root surface exposed by Streptococcus mutans," International Journal of Health Science and Research, vol. 6, no. 8, pp. 171-179, 2016.

[31] N. N. Sazwi, T. Nalina, and Z. H. A. Rahim, "Antioxidant and cytoprotective activities of Piper betle, Uncaria gambir, and betel quid with and without calcium hydroxide," BMC Complementary and Alternative Medicine, vol. 13, pp. 351-361, 2013

[32] S. Taniguchi, K. Kuroda, N. Yoshikado, et al, "New dimeric flavans from gambir, an extract of Uncaria gambir," The Japan Institute of Heterocyclic Chemistry, Okayama University, pp. 1-11, 2008.

[33] D. Shalin and C. Nicholas, "Calcium hydroxide-based root salers: A review,“ Journal of Endodontic, vol. 12, no. 4, pp. 1-5, . 2009.

[34] C. Bal, A. Alacam, T. Tuzuner, R. E. Tirali, and E. Baris, "Effects of antiseptics on pulpal healing under calcium hydoxide pulp capping: a pilot study," European Journal of Dentistry, vol. 5, no. 3, pp. 265-272, 2011

[35] J. W. M. Arts, K. Kramer, S. S. Arndt, and F. Ohi, "Sex differences in physiological acclimatization after transfer in Wistar rats," Animals (Basel), vol. 4, no. 4, pp. 693-711, 2014 
[36] V. Dwivedi and S. Tripathi, "Review study on potential activity of Piper betle," Journal of Pharmacognosy and Phytochemistry, vol. 3, no. 4, pp. 93-98, 2014.

[37] A. A. Khalil, A. A. Rahman, M. R. Khan, A. Shahar, T. Mehmood, and M. Khan, "Essensial oil eugenol: source, extraction techniques, and neutraceutical perspectives," RSC Advances vol. 2, pp. 32669, 2017

[38] T. F. Bachiega, J. P. de Sousa, J. K. Bastos, and J. M. Sforcin, "Clove and eugenol in noncytotoxic concentration exertimmunomodulatory/anti-infalamatory action on cytokine production by murine macrophages," Journal of Pharmacheutical and Pharmacology, vol. 64, no. 4, pp. 610-616, 2012

[39] K. Y. Pin, A. L. Chuah, A. A. Rashih, et al, "Antioxidant and antiinflamatory activities of Betel leaves (Piper betle) from solvents with different polarities," Journal of Tropical Forest Science, vol. 22, no. 4, pp. 448-455, 2010

[40] G. P. Kamatou, I. Vermalk, and M. Viljoen, "Eugenol-from the remote Maluku islands to the International market place: A review of a remarkable and versatiles molecule," Molecules, vol. 17, pp. 6953-6981, 2012

[41] D. Rintu, M. Shinjini, M. Kauscab, P. Pramathadhip, P. S. Umesh, and E. R. Banarjee, "Anti-oxidant and anti inflammatory activities of different varieties of Piper Leaf extract (Piper Betle L)," Journal of Nutrition and Food Science, vol. 5, no. 5, pp. 1-16, 2015

[42] N. A. Ghazali, A. Elmy, L. C. Yuen, et al, "Piper betle leave induces wound healing activity via proliferation of fibroblast and reducing 11b hydroxysteroid dehydrogenase 1- expression in diabetic rats," Journal of Ayurveda Integrated Medicine, vol. 7, no. 4, pp. 198-208, 2016

[43] E. C. Keat, S. S Razak, N. M. Fadil, et al, "The effect of Piper betle extract on the wound healing process in experimentally induced diabetic rats," Clinical Therapy, vol. 161, no. 2, pp. 117-120, 2010

[44] L. T. Lien, N. T. Tho, D. M. Ha, P. L. Hang, P. T. Nghia, and N. D. Thang, "Influence of phytochemicals in Piper betle Linn extract on wound healing. Burns and trauma," vol. 3, pp. 23-30, 2015

[45] K. C. Nilugal, K. Perumal, R. E. Ugander, and A. I. Chitton AI, "Evaluation of wound activity of Piper betle leaves and stem extract in experiment Wistar rats," American Journal of Pharmtech Research, vol. 4, no. 3, pp. 1-6, 2014

[46] A. Garg, P. Chaturvedi, and P. C. Gupta, "A review of the synthesis adverse effect of Areca nut or Betel nut," Indian Journal of Medical and Pediatric Oncology, vol. 35, no. 1, pp. 3-9, 2014

[47] J. Tham, G. Sem, E. Sit, and M. Tai, "The ethics of betel nut consumption in Taiwan," Journal of Medical Ethics, vol. 43, no. 11, pp. 739-740, 2016

[48] Q. Wu, Y. Yang, and J. E. Simon, "Qualitative and quantitative HPLC/MS determination of proanthocyanidins in areca nut (Areca catechu L.) by solvent extraction, its antioxidant activity and identification of polyphenols," Journal of Science and Food Agriculture, vol. 93, no. 10, pp. 2580-2589, 2013

[49] J. Sharafudheen, S. Goplakrishnan, P. Aneesh, and J. K. Mukkkadan, "Anti-inflammatory and antinociceptive activities of areca nut water extract," International Journal of Innovative Pharmaceutical Science and Research vol. 3, no. 4, pp. 278-284, 2015

[50] A. Hanna, S. Karan, and T. P Chatterjee, "Anti-inflammatory and analgesic activity of methanolic extract of areca seed collected from Areca catechu plant grown in Assam," International Journal of Pharmaceutical Chemistry and Science, vol. 1, no. 2, pp. 690-698, 2012

[51] P. L. Huang, C. W. Chi, and T. Y. Liu, "Effects of Areca catechu L. containing procyanidins on cyclooxygenase-2 expression in vitro and in vivo," Food Chemistry and Toxicology, vol. 48, no. 1, pp. 306-313, 2010

[52] R. R. N. Anthikat and A. Michael, "Anti-inflammatory and antioxidant effect of Areca catechu," International Journal Pharmaceutical Science and Research, vol. 3, no. 6, pp. 2031-2037, 2012.

[53] A. Vonna, Nurismir, and Misrahanum, "Wound healing activity of unguentum dosage form of ethanolic extract of Areca catechu L. nut in Mus musculus," Journal of Natural, vol. 15, no. 2, pp. 28-36, 2015

[54] D. K. Verma, M. Bharat, D. Nayak, T. Shanbhag, V. Shanbhag, and R.S. Rajput, "Areca catechu: effect of topical ethanolic extract on burn wound healing in albino rats," International Journal of Pharmacology and Clinical Science, vol. 1, no. 3, pp. 74-78, 2012

[55] M. Bharat, D. K. Verma, V. Shanbhag, R. S. Rajput, D. Nayak, and A. Amuthin, "Ethanolic effect of oral Areca catechu promotes burn wound healing in rats," International Journal of Pharmacetical Sciences Review and Research, vol. 25, no. 2, pp. 145-148, 2014.

[56] Rahmawati, Noveri, A. Fernando, and Wachyuni, "Phenolic ingredients and antioxidant activity of dried gambier (Uncaria gambir (Hunter) Roxb) leaves' extract,” Journal of Indonesia Chemical Acta,vol. 4, no. 1, pp. 1-6, 2013.

[57] Rathee, Permender, H. Chaudhary, S. Rathee, et al, "Mechanism of action of flavonoids as anti-inflammatory agents: a review," Inflammation and Allergy-Drug Targets, vol. 8, pp.229-235, 2009.

[58] T. D. Ngunyen, P. T. Thuang, I. H. Hwang, et al, "Anti-hyperuricemic, anti-inflammatory and analgesic effect of Srieges beckia orientalis L resulting from the fraction with high phenolic content," BMC Complimentary and Alternative Medicine, vol. 17, pp. 191-202, 2017 
[59] M. Yimam, Y.C. Lee, T. W. Kim, et al, "Analgesic and antiinflammatory effect of UP 3005, a botanical composition containing two standarized extracts og Uncaria gambie and Moris alba," Pharmacognosy Research, vol. 7, no. 1, pp. 39-46, 2015

[60] E. Riswana, S. Ningsih, and F. Fachrudin, "In vitro study of xanthine oxidase inhibitory of gambir (Uncaria gambir) Hunter Roxb extract," Pharmacognosy Journal, vol. 9, no. 6, pp. 862-865, 2017

[61] R. Pambayun, M. Gardjito, S. Sudarmadji, and K. R. Kuswanto, "Phenolic content and antibacterial properties of various extract of gambir (Uncaria gambir Roxb.)," Majalah Farmasi Indonesia, vol. 18, no. 3, pp. 141-146, 2007

[62] N. S. Sumosa, Efrizal, and R. Resti, "The effect of gambir (Uncaria gambir R.) in burn wound healing in male white rats Mus musculus," Journal Biologi Universitas Andalas, vol. 1, pp. 283-288, 2014.

[63] D. Septiani, E. R. Yuslianti, and S, L. Nasroen, "Effect of ethanol gambir leaves (Uncaria gambir) compared with chlorhexidine gluconate $0,2 \%$ topical for wound healing on palate mucosal galur Wistar rats," Dental Dentika Journal, vol. 18, no. 3, pp. 262-267, 2015.

[64] National Center for Biotechnology Information, "Calcium hydroxide," PubChem Database. http://pubchem.ncbi.nlm.nih.gov/compound/6093208. Accessed Dec, 19th, 2017)

[65] R. P. De Freites, V. R. Greavatti, M. P. Alcalde, et al, "Effect of the association of non streroidal anti-inflammatory and antibiotic drugs on antibiofilm activity pH calcium hydroxide pastes," Journal of Endodontic, vol. 43, no. 1, pp. 131-134, 2017

[66] S. P. Karapinar, Y. Z. A. Ulum, B. Ozcelik, et al, "The effect of N-acetylcystein and calcium hydroxide on TNF-b1 in lipopolysaccharide-activated macrophages," vol. 68, pp. 48-54, 2016

[67] A. Kasaj, B. Willershausen, M. Berakolar, H. Tekyatan, and A. Sculean, "Effect of an oily calcium hydroxyde suspension on early wound healing after non surgical periodontal theraphy," vol. 10, no. 1, pp. 72-76, 2006

[68] Y. M. Ji, S. H. Joen, J. Y. Park, J. H. Chung, Y. H. Chuong, andP. H. Chuong, "Dental stem cell theraphy with calcium hydroxide in dental pulp capping," Tissue Engineering, vol. 16, no. 6, pp. 1823-1835, 2010 